\author{
NURIA QUEROL \\ Birmingham City University
}

\title{
India at the Venice Biennale: Collateral Events From and Beyond the Nation
}

\begin{abstract}
iCon: India Contemporary (2005) was not only the first collateral event of India at the Venice Biennale, but it began as a bid to become a national pavilion - an ambition that was ultimately unsuccessful. Drawing on original research and interview data surrounding this exhibition, this article examines the collaborations and conflicts between private art institutions, artists and the state in the context of India's participation at the Venice Biennale since the 2000s. The article foregrounds a transversal approach - that is, an analytical framework that unsettles the conventional dichotomy between national pavilions and collateral events - and demonstrates how commercial galleries and private art institutions have acquired an important role in the production and exhibition of Indian contemporary art in global biennial circuits.
\end{abstract}

\section{Keywords}

iCon: India Contemporary

curating in India

Venice Biennale

collateral event

national pavilion

exhibitions histories

art and globalization 
India has played a significant role in the seminal and recently contested model of the Venice Biennale, especially given the globalization of art and transcultural curating. ${ }^{1}$ Biennials not only have become the medium through which most contemporary art comes to be known (Filipovic et al. 2010), but also through which most contemporary art is produced, curated and circulated within global art circuits. ${ }^{2}$ As the art historian Jonathan Harris usefully suggests, the global contemporary art world's players both mediate and are mediated by the biennial system, as the 'interests of curators, dealers, directors and artists may be different, aligned or antagonistic in particular moments and situations' (2017: 23). This understanding of the contextual and shifting nature of the contemporary artworld is vital to examine the Venice Biennale's dynamic and contested model, and the role that India has had within this curatorial structure.

This article examines how India's participation in the Venice Biennale has navigated the tensions between national representations and the commercialization of the arts. Focusing on the global contemporary period, India at the Venice Biennale is analyzed through a transversal approach that destabilizes established dichotomies and calls into question interrelated states. As a key intervention in curatorial studies, a transversal approach, as articulated here, brings into view a broad range of actions and timelines, not only the final exhibition but also its intentions and organizational logics. This approach accounts for the historical development, spread and orientation of India's participation in Venice with a specific focus on the exhibition iCon: India Contemporary (2005).

iCon took place in Venice as a collateral event of the 51st Venice Biennale. Curated by Peter Nagy, owner of Nature Morte Gallery in New Delhi, in collaboration with Julie Evans and Gordon Knox, iCon was not only the first collateral event of India 
at the Venice Biennale, but aspired to become a national pavilion; an ambition that was never realized. This exhibition constitutes an analytical rich case through which to establish and examine, in Harris's phrase, the 'dynamic and volatile' configurations of interests around the production and manifestation of biennial events (2017: 23). By examining a collateral event that had aspirations to become a national pavilion, this article queries hard distinctions between 'collateral events' and 'national pavilions' to draw attention to their imbricated relations (Wei 2013; Sassatelli 2017). Drawing on original interviews with curators, artists and cultural practitioners who were involved with this exhibition or commented on it, this article makes clear how contested ideas of the nation, the lack of governmental support and the rules of the art market have played significant roles in structuring India's collateral events at the Venice Biennale.

\section{India at the Venice Biennale 1954-2019: A Transversal Approach}

Following from cultural theorist Arjun Appadurai's claim that ‘history leads you outward, to link patterns of changes to increasingly larger universes of interaction' (1996: 74), I will situate iCon within its wider historical and geopolitical context. In the last decades the transformation of cultural exchanges and global dialogues in the curatorial field has had a major impact on Indian visual culture and art exhibitions. As curator and critic Gayatri Sinha has noted, 'Indian art has become increasingly global in its address, allowing curatorial objectives, the effects of new media, international residencies, art fairs, biennials, galleries, and a fluid globalized vocabulary to enter into the discourse' (2009: 19). Biennials constitute hyper-visible moments of mediation for the global contemporary art world, which are interrelated and interdependent with other global systems such as travel, commerce, tourism, investment and cultural diplomacy. 
Collateral events at the Venice Biennale refer to original exhibitions independently arranged by different organizations but still officially branded as part of the Biennale. These high-profile exhibitions are mobilized in terms of political and market instrumentalization and critical compromise, raising questions about their position in relation to national representations, pavilions and state support. It is with this awareness of both power and contingency of India's collateral participation at the Venice Biennale that I proceed with a transversal analysis in order to map moments of friction and ambiguity of these events' key art world players and socio-historical developments.

Table One. India's participation at the Venice Biennale, 1954-2019. Photo: the author.

India's participation at the Venice Biennale has long been marked by a desire to establish a national pavilion and several collateral events. In 1954, the first official exhibition of India at the Venice Biennale was organized through the Embassy of India in Rome (Ciotti 2013). Subsequent official exhibitions of India at the Venice Biennale took place in the 1950s, 1960s, 1970s and 1980s, after which India's participation at the Biennale had a hiatus of over two decades, arguably because of India's turn towards participation in global South biennials (Ciotti 2013; Bhuyan 2013). It was not until the 2000s when the debates on India's participation at the Biennale and the need to establish an official representation came to the fore. Not surprisingly, this coincided with the burgeoning strength of Indian contemporary art globally and an increased presence of Indian artists in biennials worldwide (D'Souza 2017; Querol forthcoming).

As indicated in Table One, since the 2000s India has been represented in Venice through collateral events and national pavilions, alongside several unsuccessful 
exhibition attempts. The history of India's participation at the Venice Biennale is not linear or teleological: there is no forward thrust, but intentions and ambitions, some realized, some thwarted. Robert Storr, artistic director of the Venice Biennale in 2007, offered a space for an India national pavilion in his edition. Surprisingly, there was no response from the Indian government; this was symptomatic of the lack of state support towards contemporary art. In 2009 the global financial crisis saw the undoing of a collateral event planned by the now defunct Bodhi Art Gallery. Curators and private galleries have attempted, with varying degrees of success, to engage the Indian government in supporting official representations at the Venice Biennale. The first collateral event took place in 2005 with the exhibition $i$ Con, discussed in more detail below. The second collateral event, My East is Your West (2015), organized by India's private philanthropic institution The Gujral Foundation, brought together the conflicting nations of India and Pakistan in a shared exhibition platform to explore 'a complex climate of historical relations' (Gujral 2015: 9). In between these events, Everyone Agrees: It's About to Explode... (2011), curated by Ranjit Hoskote and organized by the Lalit Kala Akademi, marked the first India national pavilion at the Venice Biennale. This official representation was then discontinued. A retreat that led the prominent Indian artist Bharti Kher (2013) to publicly issue a letter of complaint, extracts of which illustrate a discourse around Indian government apathy and misunderstandings that surfaced in some of my artist interviews:

\section{To Whom It May Concern (if at all)}

As I sit these mornings and look at my mailbox something about where I'm from and at bothers me as the news from Venice Biennale filters in: pavilions from Angola (population 19.6 million, civil wars 1975 to 2002) Azerbaijan (9.173 
million) Bangladesh, Tuvalu (population 9,847) ... yes smaller than Lajpat Nagar! Iraq, Kuwait, Maldives, Montenegro, special participations from Palestine, Tibet.... etc. We didn't bother to make it happen. Again. It's a catalyst perhaps to move, a truth of other happenings that remain unresolved. Nagging issues that plague us in India [...].

When we sent our specialists (I heard 35 or so) from the Indian government last year to witness our first participation in 116 years, with their junkets and icecream coupons, didn't they see that Venice was about the art and sharing of ideas and not fake handbags or collecting masks? [...] You can say, "who cares"... nationalist agendas are not relevant anymore. I agree. Art is not relevant because it cannot change the world. I agree. But we can't escape apathy and indifference and I'm not talking about politics, I'm talking about love.

There is a stark contrast here to the discourse that surrounds the Indian pavilion at the 58th Venice Biennale six years later in 2019, India's second national pavilion since 2011. Dedicated to exploring the philosophies and cultural legacies of Mahatma Gandhi, Our Time for a Future Caring, differs markedly from Kher's letter in receiving an expression of state support.

Kher critiques the Indian government's perceived lack of interest in 'art and [the] sharing of ideas', as well as the disavowal of nationalist agendas. This critique can be counter-posed with the press release surrounding India's presentation at the Venice Biennale in 2019. The joint secretary of the Ministry of Culture, Nirupama Kotru, is quoted as saying, 'Art is nothing but an expression of a nation's culture', before celebrating 'the universal Gandhian values of truth, non-violence, [and] compassion' 
explored in installations and artworks (Kiran Nadar Museum of Art 2019). India's participation at the 58th Venice Biennale is described by key stakeholders, including the government's taskforce on Art and Culture, as 'an important milestone.' As a quote from Tarana Sawhney, Chairperson of this taskforce indicates, the 2019 pavilion 'brings together, for the first time, both the Ministry of Culture and private art institutions to showcase contemporary art from our country to a world audience. It is projects like these that raise interest and change perceptions' (Kiran Nadar Museum of Art 2019). Here, the state support is markedly different from the perceptions of withdrawal and neglect in Kher's letter (2013). In the India Pavilion (2019) the state clearly embraces art as a way to articulate nationalist agendas and values on a global stage, putting the figure of Gandhi and ideas of care and compassion as central messages to share Indian culture to the world.

The India Pavilion in 2019, and the official discourses, sets up an interesting problematic that will be explored in the rest of the article. Why have there only been two official presentations by India at the Venice Biennale in contemporary global times, and what, historically, have been the collaborations and conflicts between private art institutions, artists, and the state? By examining both what has taken place, and what has been proposed but never manifested, the role and relation of collateral events and national pavilions within a globalized art world can be better understood. The collateral event $i$ Con exemplifies these frictions and ambiguities.

\section{iCon: India Contemporary: Between a National Pavilion and a Collateral Event}

The exhibition iCon was an official collateral event of the 51st Venice Biennale in 2005. It was organized by Sally and Don Lucas Artists' Programs at Montalvo Arts Center (California), with the support of commercial art galleries Nature Morte (New Delhi) and 
Bose Pacia (New York) and the Venetian organization Nuova Icona. This structure responded to the Venice Biennale's procedure related to collateral events, where exhibitions cannot be directly commercially funded and must be proposed by a 'promoter' organization (Hyde 2017).

The curators were Peter Nagy, founder and gallery director of Nature Morte, Gordon Knox, at the time artistic director of Montalvo Arts Centre, and painter Julie Evans. According to Nagy, the decision to organize an Indian contemporary art exhibition for the Venice Biennale came after realizing the lack of an India pavilion during an earlier visit to the Biennale in 2003 (Nagy 2005). Two years later iCon materialized to showcase the work of five artists and one collective representing the vital and engaging art practices to be found in India today' (Evans et al. 2005). The artists selected included Atul Dodiya, Anita Dube, Ranbir Kaleka, Nalini Malani, Nataraj Sharma and Raqs Media Collective (Monica Narula, Jeebesh Bagchi and Shuddhabrata Sengupta), all leading names in the Indian art scene who have exhibited widely in biennials around the world. ${ }^{3}$ Crucially, the press release claimed that 'In the modern history of the Biennale, Venice has not seen an India Pavilion', a statement indicative of the curators' original intentions to establish an official national representation (Evans et al. 2005).

Notably, the curators aimed for iCon to become an Indian national pavilion, an ambition that was never realized. This aspiration was expressed in the Montalvo Arts Center website, which referred to $i$ Con as 'a pavilion representing Indian artists at the 2005 Venice Biennale' (Montalvo Arts Center 2005). Here, the use of the term 'pavilion' contrasts with the Venice Biennale's present communication policy that states: 'it is not possible to use the term "pavilion" with reference to Collateral Events' (La Biennale di Venezia 2019). The Biennale's policy clearly asserts a distinction between 'pavilions' 
and 'collateral events'. Commenting on this division, sociologist Monica Sassatelli has noted the 'increasing number of collateral events that are not officially national participations, but clearly imagine themselves as such' (2017: 104). iCon certainly imagined itself as an official national participation. Referring to their initial disposition to establish a national pavilion, and their unsuccessful attempt, curator Peter Nagy (2008) noted their unrealized ambition due to lack of state support:

When we [referring to himself and fellow curators Evans and Knox] started the project, we hoped that it would be the official Indian pavilion and we approached the government to get them involved. We were not even asking them for money, we were just asking them for support. Because in the context of the Venice Biennale you cannot be an official pavilion unless you have some official letter from some Department of Culture or something like that from the government. You don't need the financial support of the government. But you do need the stamp of approval and the formal recognition. We tried to get that, and we were not able to.

By failing to achieve an alliance with the Indian state, $i$ Con fell short in becoming a national pavilion, marking a disjuncture between the curator's ideals and the circumstances at the time. Nagy, who has lived in New Delhi since the early 1990s and is familiar with the art world and cultural politics in India, expressed perplexity at the Indian government's refusal to be involved with the exhibition (Nagy 2008). Significantly, Nagy's use of the word 'official' to refer to the collateral event, and his emphasis that funding was not a factor involved in their demands, suggest the complex politics of cultural representation and legitimacy at the Venice Biennale, and the role of 
state and corporate support. ${ }^{4}$ As art theorist Panos Kompatsiaris states, 'Apart from values related to cultural agendas, a biennial also enacts values through the ways it relates with economic agendas' (2017: 26, original emphases). Biennials indeed mediate and are mediated by political, cultural and economic interests.

The official lack of support for iCon reflected India's disregard for contemporary art since the state's adoption of neoliberal financial policies in the 1990s. ${ }^{5}$ As cultural theorist Rustom Bharucha (2010) notes, 'the Indian state has not matched this cultural investment [referring to the funding invested by overseas cultural agencies and art enterprises] apart from short-term opportunistic forays in the now moribund area of the "festivalisation" of Indian culture abroad'. Shortages in cultural funding and, as art critic and curator Geeta Kapur (2011) contends, the fact that 'many state institutions dealing with the arts are run by bureaucrats with no background in art history, contemporary criticism or curatorial experience' has reinforced a dearth of interest and support of the Indian state towards contemporary art. In this context, corporate sponsorship and commercial art galleries have played a significant role in exhibiting contemporary Indian art internationally.

When discussing India's participation at the Venice Biennale, interviewees often mentioned the ignorance of senior bureaucrats about what the Venice Biennale is, the dearth of funds and resources, and the Indian government's inefficiency. Remarking on government's negotiation with the iCon curators, Nagy pointed out that 'We were met [by the Indian government] with nothing but inertia and apathy every step of the way' (Art Basel Miami 2007: 71). Nagy's comments echo Bharti Kher's 'letter of complaint', which drew attention to the government's apathy and inaction but also to India's lost opportunity to participate in international cultural exchanges. A national pavilion in Venice is a powerful tool of cultural diplomacy (Ghose 2015; Sassatelli 2017). Yet, while 
many artists and curators shared a concern about India not having a pavilion, they expressed discomfort about national representations and singular ideas of the nation.

\section{The National Conundrum}

The Venice Biennale's system of national representations, inherited from nineteenthcentury world fairs, is deemed by some as an anachronistic exhibition model in present times. ${ }^{6}$ Critics have long remarked on national bias in artist selections and pavilion allocations (Wu 2009; Green and Gardner 2016). In iCon, the tensions of national framings were further complicated by singular ideas of the nation and how national representations are contested through artworks that simultaneously are being circulated and reterritorialized through biennial structures.

In reference to national representations and India's participation at the Biennale, Nalini Malani (2008), one of the artists selected for iCon, stated the disjuncture between the state and national art narratives: 'the thing is the Indian government, plus the national discourse of modern art, are not cooperating to have an official presentation of India at Venice'. This statement reflects the controversy at that time about the lack of state support towards an India Pavilion, but also expresses a critique on the construction and centralism of single modern narratives of the nation and its art. Malani addressed this critique in five-channel video installation Mother India: Transactions in the Construction of Pain (2005), produced while in residency at Montalvo Art Centre for the iCon exhibition. Mother India uses references to Indian traditional art and mythology combined with images from the anti-Muslim Gujarat genocide of 2002 and the IndiaPakistan Partition in 1947. This combination of visual imaginaries, politics, traditions and hegemonic powers offers a critical reflection on the construction of the nation and the infliction of violence in this national construct, especially sexual violence against 
women. Drawing on sociologist Veena Das (1997), Malani commented in the exhibition catalogue about the problematic idea of the nation: 'In a sense this is a work [referring to Mother India] in line with my video Unity in Diversity [2003] which addresses the dissolution of this very concept that India as a nation state started out with' (Pijnappel 2005). This address, however, might have not been valid in the context of a national pavilion, especially since Mother India challenges the glorification of certain national narratives by governing bodies; the same governing bodies from which a national pavilion would have needed formal recognition and approval.

The complexities of national representations in the context of biennials and global exhibitions is discussed by Raqs Media Collective, also a part of $i$ Con, with the installation A Measure of Anacoustic Reason (2005). As Jeebesh Bagchi (2009), one of the members of the collective, put forward stating their position on their work ethos and location: 'we work in a post-national space, where the question of nationality or where you are coming from is not important, but instead what matters is your discursive framework and your capacity for producing a body of work'. This commentary was prompted by a discussion on wider curatorial strategies and the challenges of the survey exhibition model. Survey exhibitions prevailed during the 2000s when showcasing contemporary art from India in international circuits and was repeatedly criticized by my interviewees for standardizing artists' identities and artworks through fixed geographic boundaries and national frameworks. ${ }^{7}$

iCon was a survey exhibition, but rather than being staged as a national pavilion it appeared as a collateral event. In the press statement, the curators situated the artists as representative of contemporary art practices that could 'be found in India today', and described the country as 'a unified and democratic nation' that in its diversity could be 'a model for how other nations may resolve the anxieties presented by globalization and 
post-modernism' (Evans et al. 2005). Yet, these statements in effect reterritorialized the artists and artworks by categorizing them as Indian art representatives. iCon exerted a national unified model in the globalizing curatorial proposition, succumbing to what Geeta Kapur has described as 'the dubious glamour of the India banner' (2012: 171). Kapur, who has long articulated a discourse on Indian art from a national leftist commitment, has also questioned the national format and its limitations 'to produce something different in the name of India'. As she contends, 'the "big" exhibition needs to be re-imagined so as to function as a constellatory site for new questions' (Kapur 2011). The need to reimagine the national exhibition model has certainly been central in the context of the Venice Biennale in the last decades, and in the various participations of India in biennials and international art circuits.

Given the controversy of national representations and structures of $i$ Con, it is useful to tease out points of convergence and divergence with the 2011 India national pavilion Everyone Agrees: It's About to Explode..., curated by Ranjit Hoskote. Referring to his curatorial vision, Hoskote (2013) recalls the limitations of national projects and identities:

We [referring to himself and fellow curator Nancy Adajania] tend to be wary of how the national project sometimes takes unproductive forms. It can continue with colonial reflexes articulated through State mechanisms. Or it can develop pathologies of oppressiveness that are phrased as a defense of a 'national culture' that is essentially mainstream or majoritarian. Or it can hold on to expressions of identity that were legitimate in the early postcolonial period of the 1950s and 1960s, but have become irrelevant to an experience of the world that is no longer confined to the national territory, and has not been for a long time. Our 
experience as writers and curators is transnational, transcultural. For us it is important to create significance beyond national borders, to embrace a cosmopolitan project that is self-consciously a work in progress, a workingthrough of affinities and questions.

The complexities of national representations entangled with curatorial propositions of transnational and transcultural ideals was indeed made manifest in the first India Pavilion at the Venice Biennale in 2011. ${ }^{8}$ Following the global curatorial strategy of the Venice Biennale since 1990s, Hoskote's aim 'to create significance beyond national borders' questioned the logic of national representations and critiqued the idea of the nation as something unitary or territorial, while addressing diverse religions, regional modernities and diasporic identities (Hoskote 2011). Interestingly, Hoskote consciously selected artistic practices not directly associated with the Indian art market and the gallery system, in contrast to previous participations of India at the Venice Biennale, particularly the collateral event iCon.

\section{The Ambivalence of the Art Market}

The role played by the art market became another focus of critique in iCon. Critics of the biennial model have long discussed the complicity of these large-scale exhibitions with globalized neoliberalism and the commercialization of the arts. As the art historian Julian Stallabrass elaborates on the relationship between biennials and market interests: 'while biennials are powerful magnets for the attention of the art market, they are also frequently complicit within those markets and within the commodification of art' (2004: 34-35). For Stallabrass, the efficacy of the biennial model is frequently undermined by the specifics of the curatorial context and market-driven interests. In the case of $i$ Con, 
considering that curator Peter Nagy is the founder and director of the commercial art gallery Nature Morte, the complicity with art market forces raised suspicions about the selection of artists and the legitimacy of a commercial art gallery to stage a national pavilion.

iCon clearly had a commercial angle. This was evident in the artists selected as well as the funds involved to stage this collateral event. Referring to the financial logistics and the curators' choice of artists, Peter Nagy (2008) stated that the exhibition scale plus commercial concerns were a driving force behind their curatorial selection:

We produced video works for Raqs Media Collective, Nalini Malani and Ranbir Kaleka [all produced while in residency at Montalvo Art Centre] [...]. And we found a space that was bigger than we actually imagined and that is when we realized we could add on more material. But simply out of financial logistics, if we were going to make a bigger show, how were we going to help fund this? Well, then, we thought we would bring in painting and sculpture which we would be able to sell easily, which would go back into funding this [collateral event].

Space and funding indeed played a role in the curators' choices, but also artists' global exposure and gallery connections. The majority of the artists in $i$ Con belong to the select group of artists in India most exhibited in global biennial circuits. Commonly known as 'the usual suspects', as named by art critic Girish Shahane (1999), these artists are represented by prominent commercial galleries, denoting a higher circulation of Indian artists who are well-established in the global art market. In this context, the selection of paintings and sculptures in iCon that Nagy referred to as being 'able to sell easily' 
(2008), was not only a commercially driven decision but also a strategic one in order to include Nature Morte's artists. Unsurprisingly, the curators selected the works of Anita Dube, Nataraj Sharma and Atul Dodiya, all of whom were represented or had exhibitions at Nagy's gallery in Delhi, or at partner gallery Bose Pacia in New York. In this regard, as theorist Peter Osborne has noted, 'biennials are now, even if only indirectly, an integral part of such [capitalist] production' (2015: 26). Acknowledging that the works of iCon were for sale, Nagy (2008) notes iCon's role within the structure of collateral events as an example of the 'commercialization of the Venice Biennale':

We could only afford to keep [iCon] up until the end of July so we could not afford to keep it up for the full run of the Biennale. We paid 6,000 euros to become what is called an official collateral event to the Venice Biennale, which meant we were in the catalogue, on official maps, and able to put our material into the official press offices. That was in 2005. By 2007 to get the same thing would cost 24,000 euros so what I think we were seeing [was] the beginning of the commercialization of the Venice Biennale.

This comment refers not only to iCon but also to Nagy's second unsuccessful attempt in 2007 to establish an India national pavilion. According to Nagy, the quadrupling of the collateral event admission fee in just two years corresponded with an incipient commercialization of the Venice Biennale. His comment not only downplayed the previous history of the Biennale, where until 1968 artworks were for sale, but also the present conditions of dialogism between biennials, art fairs and the art market logic, notably with Art Basel which, as art historians Charles Green and Anthony Gardner have noted, 'is usually scheduled a short period of weeks after the Venice vernissage' 
(2016: 228). In addition, the fact that collateral events are officially branded as part of the Biennale upon payment of a fee relates to not only commercial sponsorships in Venice but also to the global neoliberal politics involved in Biennale pavilion selections. In India, the collateral event $i$ Con called attention to the global interest that contemporary Indian art received in the 2000s and its imbrication with the art market boom. Commenting on the ambivalent position of the art market and the tensions of national representations, one of my interviewees commented anonymously that Nature Morte, as a private gallery, should not organize an official representation: ${ }^{9}$

Why should Nature Morte represent India at the Venice Biennale? I find that problematic. Who decides this? On the basis of what? I agree that India has to be in Venice but there is some fundamental problem that a private institution with its own set of artists saying that we represent the country.

(Anonymous 2008)

This comment questioned the legitimacy of Nature Morte's efforts to position iCon as a national pavilion. Discussing Nagy's unsuccessful attempts in 2005 and 2007, arts journalist Anindita Ghose stated the challenges in establishing alliances between governmental units and private funding bodies: 'For a country to endorse a private exhibition can be a tricky matter, as personal and commercial agendas can then be confused with public ones' (2015). This was an opinion shared by the majority of people with whom I discussed India's participation at the Venice Biennale. The recurrent concern within the art scene in India at that time was the feeling that the market was the only institution that worked in the country. 
Although the prevalence of the art market in India has been criticized, one should not ignore the benefits it has generated. Artists pointed to the travel and opportunities arising from acquiring global exposure, which in turn translated into a flourishing art scene and financial success. Nagy and Nature Morte played a leading role in helping artists to achieve international acclaim. In this regard, art historian Kavita Singh (2008) refers to 'export art' not in terms of capitulation to foreign audiences or artists' cannibalization of their own culture, but instead as a field of endless possibilities, underlining artists' agency and autonomy. Acknowledging both the favorable aspects and the dangers of market success and biennial exposure, this entanglement has generated a broader reflection on politics and economics in the artistic field. In this context, the art market can be seen ambivalently, not only as a means to achieve global success but also as a way to establish alternatives away from hegemonic and nationalist discourses of art.

The fact that iCon did not succeed in becoming a national pavilion was mainly due to the lack of governmental support, but other reasons came into play. Artists and curators were suspicious about a private institution with commercial interests wanting to represent the country. At the same time, Nature Morte's proposal raised critiques on how the Venice Biennale model of national representation could potentially reinforce single national narratives exerted by governing bodies. With regard to establishing a national pavilion, the interests of governmental units, private funding bodies, local institutions and the art community need to converge. Given that the Indian national pavilion has received only intermittent state support, there seems to be a need for alliances with private bodies and the market as a pre-condition for both the establishment and survival of India collateral events, and perhaps future national pavilions, that present transnational and even anti-hegemonic ideals. 
With regard to national representations and constructs, iCon: India Contemporary raised critiques relating to how the Venice Biennale model, and the cultural investment of governing bodies, can reinforce the glorification of certain national narratives. These tensions were directly addressed in the India national pavilion in 2011. The loss of governmental support created extremely challenging circumstances for the continuity of the India national pavilion, which has only recently re-emerged at the Venice Biennale in 2019. Overall, the participation of India at the Venice Biennale throws into question established institutional, ideological and economic issues. As curator Natasha

Ginwala has noted about the web of power relations behind exhibition histories: 'As a live medium, an exhibition is a site of production, a social persona, a constellation of narratives and a shared conversation. The voices within exhibitions constitute an observable politics, but what often go unnoticed are the silences' (2011: 15, original emphases). Ultimately, exploring the role of collateral events associated with India's participation at the Venice Biennale requires unpacking a set of social, political, economic and artistic relations. A transversal approach, moving between the macro and the situated, between official discourses and embodied interpretations, brings into view the vexed relations between the 'national' and the 'collateral' to question the imbricated relationship of biennials and the art market, and of national and global imaginaries.

\section{References}

Anonymous curator (2008), interview with the author, 14 November. Appadurai, Arjun (1996), Modernity at Large: Cultural Dimensions of Globalization, Minneapolis: University of Minnesota Press. 
Art Basel Miami (2007), 'The Museum of the Future in India', Art Basel Conversations Transcripts, Basel: Art Basel Conversation Publications, pp. 59-90.

Bagchi, Jeebesh (2009), interview with the author, New Delhi, 6 January.

Bharucha, Rustom (2010), 'Cultural Exchange and Civil Society in Asia: A Perspective from India', Asia Art Archive Diaaalogue, https:/ / aaa.org.hk/en/ideas/ideas / cultural-exchange-and-civil-society-in-asiaa-perspective-from-india. Accessed 5 April 2019.

Bhuyan, Ragini (2013), 'India First Went to Biennale in 1954', Sunday Guardian, 10 August, http:/ / www.sunday-guardian.com/artbeat/india-first-went-tobiennale-in-1954. Accessed 5 April 2019.

Bublatzky, Cathrine (2019), Along the Indian Highway: An Ethnography of an International Travelling Exhibition, New Delhi: Routledge India.

Bydler, Charlotte (2004), The Global Artworld, Inc.: On the Globalization of Contemporary Art, Uppsala: Uppsala Universitet.

Ciotti, Manuela (2013), 'Untold Histories: India at the Venice Biennale since 1954', Foundation for Indian Contemporary Art Talk, 8 August, https:// www.facebook.com/events/217659738390966. Accessed 5 April 2019. Das, Veena (1997), 'Language and Body: Transactions in the Construction of Pain', in Arthur Kleinman, Veena Das and Margaret Lock (eds), Social Suffering, Berkeley: University of California Press, pp. 67-91.

D'Souza, Robert E. (2017), 'The Indian Biennale Effect', in Robert E. D'Souza and Sunil Manghani (eds), India's Biennial Effect: A Politics of Contemporary Art, London and New York: Routledge, pp. 25-57.

Enwezor, Okwui (2015), All the World's Futures: 56th International Art Exhibition, Venice: Marsilio Editori for La Biennale di Venezia. 
Evans, Julie, Knox, Gordon and Nagy, Peter (2005), 'iCon: India Contemporary - Press Release', http:/ / universes-in-universe.de/car/venezia/bien51/eng/ind/text1.htm. Accessed 5 April 2019.

Filipovic, Elena, Van Hal, Marieke and Øvstebo, Solveig (2010) (eds), The Biennial Reader: The Bergen Biennial Conference, Bergen: Hatje Cantz Verlag.

Ghose, Anindita (2015), ‘Far Pavilions: Why India Must Participate in the Venice Biennale', The Caravan, 1 June, https:/ / caravanmagazine.in/perspectives/farpavilions-venice-biennale-india. Accessed 5 April 2019.

Ginwala, Natasha (2011), 'In Hindsight: An Ode to Forgetting and Inexactness', in Natasha Ginwala and Vidya Shivadas (eds), Take on Art-Special Issue on Curation, 2:1, pp. 14-15.

Green, Charles and Gardner, Anthony (2016), Biennials, Triennials and documenta: The Exhibitions that Created Contemporary Art, Chichester: Wiley-Blackwell.

Gujral, Feroze (2015), 'My East Is Your West: An Artistic Address from South Asia', in The Gujral Foundation, My East Is Your West, Noida: HarperCollins, pp. 10-13. Harris, Jonathan (2017), The Global Contemporary Art World, Chichester: Wiley-Blackwell. Hoskote, Ranjit (2009), 'Patriotism and the Art Pavilion', Times of India, 9 August, https: / / timesofindia.indiatimes.com/ city / mumbai / Patriotism-and-the-artpavilion/articleshow/4872381.cms. Accessed 5 April 2019.

Hoskote, Ranjit (2011), ‘Pavilion as Laboratory. A Tool Box for “Everyone Agrees: It's About to Explode"', in Lalit Kala Akademi, Everyone Agrees: It's About to Explode... The India Pavilion at the 54th Venice Biennale 2011, New Delhi: Lalit Kala Akademi Publications, pp. 1-10.

Hoskote, Ranjit (2012), ‘Opening Statement - TAKE / Biennale Roundtable', in Ranjit Hoskote (ed.), Take on Art-Special Issue on Biennales, 2:8, pp. 40-47. 
Hoskote, Ranjit (2013), interview with the author, Mumbai, 8 March.

Hyde, Sarah (2017), 'How to Get a Satellite Show During the Venice Biennale', Artnet News, 8 February, https:/ / news.artnet.com/art-world/ satellite-show-duringvenice-biennale-849362. Accessed 5 April 2019.

Jhaveri, Shanay, Geir, Haraldseth, Stocchi, Francesco and Lu, Carol Yinghua (2013), 'Assessments: Indian Highway', The Exhibitionist, 7, pp. 39-54.

Jones, Caroline A. (2016), The Global Work of Art: World's Fairs, Biennials and the Aesthetics of Experience, Chicago: University of Chicago Press.

Kapur, Geeta (2011), 'On the Curatorial in India (Part $1 \& 2$ )', interview by Natasha Ginwala, Afterall Online, 12 July, http:/ / www.afterall.org/online/geeta-kapurpart1. Accessed 5 April 2019.

Kapur, Geeta (2012), 'Curating Across Agonistic Worlds', in Sabin Iqbal (ed.), Against All Odds - 1st Kochi-Muziris Biennale, Kottayam: DC Books, pp. 161-77.

Kher, Bharti (2013), 'On India's Absence at the Venice Biennale', The Saffronart Blog, 28 May, https:/ / blog.saffronart.com/2013/06/30/bharti-kher-on-indias-absenceat-the-venice-biennale. Accessed 5 April 2019.

Kiran Nadar Museum of Art (2019), 'Press Release - Artist Line-up Announced for India Pavilion at 58th International Art Exhibition at La Biennale di Venezia', http:/ / www.knma.in/ press-release-artist-line-announced-india-pavilion-58thinternational-art-exhibition-la-biennale-di. Accessed 5 April 2019.

Kompatsiaris, Panos (2017), The Politics of Contemporary Art Biennials: Spectacles of Critique, New York and Abingdon: Routledge.

La Biennale di Venezia (2019), ‘Procedure for Collateral Events. 58th International Art Exhibition', https: / / static.labiennale.org/files/arte/ Documenti/58eia-evcollen.pdf. Accessed 5 April 2019. 
Malani, Nalini (2008), interview with the author, Mumbai, 26 November.

Martini, Federica and Martini, Vittoria (2011), Just Another Exhibition: Histories and Politics of Biennials, Milano: Postmedia Books.

Mesquita, Ivo (2003), ‘Biennials, Biennials, Biennials, Biennials, Biennials, Biennials, Biennials', in Melanie Townsend (ed.), Beyond the Box: Diverging Curatorial Practices, Banff: Banff Centre Press, pp. 63-68.

Montalvo Arts Center (2005), 'Participants', http:/ / montalvoarts.org/participants/nalini_malani/. Accessed 5 April 2019.

Nagy, Peter (2005), ‘Floating Towards Venice', Asia Art Archive Diaaalogue, https:/ / aaa.org.hk/en/ideas/ideas/floating-towards-venice/type/ notes. Accessed 5 April 2019.

Nagy, Peter (2008), interview with the author, New Delhi, 5 November.

Niemojwski, Rafal (2010), 'Venice or Havana: A Polemic on the Genesis of the Contemporary Biennial', in Elena Filipovic, Marieke van Hal and Solveig Ostevo (eds), The Biennial Reader, Bergen and Ostfildern: Bergen Kunsthall and Hatje Cantz, pp. 88-103.

O'Neill, Paul (2012), The Culture of Curating and the Curating of Culture(s), Cambridge, MA: MIT Press.

Osborne, Peter (2015), 'Every Other Year Is Always This Year: Contemporaneity and the Biennial Form', in Charles Esche, Galit Eilat, Nuria Enguita Mayo, Pablo Lafuente, Luiza Proença, Oren Sagiv and Benjamin Seroussi (eds), Making Biennials in Contemporary Times: Essays from the World Biennial Forum No. 2, Amsterdam: Biennial Foundation; São Paulo: Fundação Bienal de São Paulo; São Paulo: Instituto de Cultura Contemporânea, pp. 15-27. 
Oza, Rupal (2006), The Making of Neoliberal India: Nationalism, Gender and the Paradoxes of Globalization, New York and London: Routledge.

Pijnappel, Johan (2005), 'Interview with Nalini Malani', iCon: India Contemporary, 51st

Venice Biennale, http:/ / www.nalinimalani.com/texts/venice.htm. Accessed 5 April 2019.

Querol, Nuria (forthcoming), Transcultural Curating: Contemporary Indian Art in a Global Context, Liverpool: Liverpool University Press.

Ricci, Clarissa (2010) (ed.), Starting from Venice: Studies on the Biennale, Milan: Et.al. Sassatelli, Monica (2017), 'Symbolic Production in the Art Biennial: Making Worlds', Theory, Culture and Society, 34:4, pp. 89-113.

Shahane, Girish (1999), 'The Usual Suspects', ART India Magazine, 4:2, pp. 36-37.

Singh, Kavita (2008), 'Where in the World', in Kavita Singh, Deepti Mulgund, Jaya Neupaney and Shweta Wahi (eds), Where in the World, New Delhi: Devi Art Foundation, pp. 5-15.

Sinha, Gayatri (2009), 'Introduction', in Gayatri Sinha (ed.), Arts and Visual Culture in India, 1857-2007, Mumbai: Marg Publications, pp. 8-23.

Stallabrass, Julian (2004), Art Incorporated: The History of Contemporary Art, Oxford: Oxford University Press.

Wei, Chu-Chiun (2013), 'From National Art to Critical Globalism: The Politics and Curatorial Strategies of the Taiwan Pavilion at the Venice Biennale', Third Text, 27:4, pp. $470-84$.

Wu, Chin-Tao (2009), 'Biennials Without Borders?', New Left Review, 57 (May-June), pp. $107-15$.

\section{Contributor Details}


Nuria Querol is Senior Lecturer in Art Theory in the Birmingham School of Art at Birmingham City University. Her research interests include contemporary art politics, curatorial studies, and issues of globalization, transculturality and decoloniality, primarily in Asia and the Global South. Querol has published in journals and in specialized publications such as Dialogues on Curating and the UNESCO's World Report on Cultural Diversity (2008). She contributes to numerous art journals, including ExitBook, ExitExpress and Contrastes Journal. Her forthcoming monograph Transcultural Curating: Contemporary Indian Art in a Global Context will address how transcultural exhibitions position Indian contemporary art globally.

Contact: Birmingham School of Art, Birmingham City University, Margaret Street, Birmingham B3 3BX, UK.

Email: nuria.querol@bcu.ac.uk

${ }^{1}$ On biennials and globalization, see Niemojwski (2010) and Green and Gardner (2016). On India, see Kapur (2012) and Hoskote (2012).

${ }^{2}$ See Bydler (2004), O’Neill (2012) and Sassatelli (2017).

${ }^{3}$ From the late 1980s until the early 2000s, the participation of Indian artists in biennials took place mainly in recurring exhibitions in Asia and the global South. Biennials such as Havana, Johannesburg, Gwangju, Shanghai, Asia-Pacific Triennale in Brisbane and Fukuoka Asian Art Triennale all exhibited contemporary Indian artists during this period. See Kapur (2012), Green and Gardner (2016) and Querol (forthcoming). ${ }^{4}$ See Ricci (2010), Martini and Martini (2011) and Jones (2016). 
${ }^{5}$ The last decades have been a crucial period for shifts in India's financial policies following the neoliberal reform instituted in 1991, which strengthened India's encounter with global capital. This shift saw India move from economic protectionism with strong socialist ties after its independence in 1947, to adopting neoliberal economic policies as part of the conditions of development loans from global governance institutions such as the World Bank and the International Monetary Fund. See Oza (2006).

${ }^{6}$ See Mesquita (2003), Niemojwski (2010) and Enwezor (2015).

${ }^{7}$ Some of the most prominent survey exhibitions of Indian contemporary art in the 2000s were Kapital and Karma: Recent Positions in Indian Art (2002), Edge of Desire: Recent Art from India (2005-07), Chalo! India: A New Era of Indian Art (2008-09), Indian Highway (2008-12) and Paris-Delhi-Bombay... (2011). For an account on the model of survey shows through the case of the Indian Highway exhibition, see Jhaveri et al. (2013) and Bublatzky (2019).

${ }^{8}$ Surprisingly, two years earlier, Ranjit Hoskote (2009) published an article against the need for an India pavilion at the Venice Biennale. The fact that a couple of years later he curated the first India Pavilion in Venice accentuates the disjuncture between a global artworld with hegemonic and reterritorializing attitudes and of curators and artists with antihegemonic and post-national ideals but caught in-between the codes and rules of the global artworld itself.

${ }^{9}$ On the ethical questions pertaining to the identities of my interview participants, this proceeded on a case-by-case basis. On deciding whether to be named in the interview or to be made anonymous, I followed their requests. 